\title{
A case study of field-scale maize irrigation patterns in western Nebraska: implications for water managers and recommendations for hyper-resolution land surface modeling
}

\author{
Justin Gibson ${ }^{1}$, Trenton E. Franz ${ }^{1}$, Tiejun Wang ${ }^{1,2}$, John Gates ${ }^{3}$, Patricio Grassini ${ }^{4}$, Haishun Yang ${ }^{4}$, and \\ Dean Eisenhauer ${ }^{5}$ \\ ${ }^{1}$ School of Natural Resources, University of Nebraska-Lincoln, Lincoln, NE, USA \\ ${ }^{2}$ Institute of Surface-Earth System Science, Tianjin University, Tianjin 300072, P. R. China \\ ${ }^{3}$ The Climate Corporation, San Francisco, CA, USA \\ ${ }^{4}$ Department of Agronomy and Horticulture, University of Nebraska-Lincoln, Lincoln, NE, USA \\ ${ }^{5}$ Biological Systems Engineering Department, University of Nebraska-Lincoln, Lincoln, NE, USA \\ Correspondence to: Trenton E. Franz (trenton.franz@unl.edu) and Justin Gibson (jgibson8@ huskers.unl.edu)
}

Received: 26 August 2016 - Discussion started: 30 August 2016

Revised: 9 December 2016 - Accepted: 31 January 2017 - Published: 20 February 2017

\begin{abstract}
In many agricultural regions, the human use of water for irrigation is often ignored or poorly represented in land surface models (LSMs) and operational forecasts. Because irrigation increases soil moisture, feedback on the surface energy balance, rainfall recycling, and atmospheric dynamics is not represented and may lead to reduced model skill. In this work, we describe four plausible and relatively simple irrigation routines that can be coupled to the next generation of hyper-resolution LSMs operating at scales of $1 \mathrm{~km}$ or less. The irrigation output from the four routines (crop model, precipitation delayed, evapotranspiration replacement, and vadose zone model) is compared against a historical field-scale irrigation database (2008-2014) from a $35 \mathrm{~km}^{2}$ study area under maize production and center pivot irrigation in western Nebraska (USA). We find that the most yield-conservative irrigation routine (crop model) produces seasonal totals of irrigation that compare well against the observed irrigation amounts across a range of wet and dry years but with a low bias of $80 \mathrm{~mm} \mathrm{yr}^{-1}$. The most aggressive irrigation saving routine (vadose zone model) indicates a potential irrigation savings of $120 \mathrm{~mm} \mathrm{yr}^{-1}$ and yield losses of less than $3 \%$ against the crop model benchmark and historical averages. The results of the various irrigation routines and associated yield penalties will be valuable for future consideration by local water managers to be informed about the potential value of irrigation saving technologies and irrigation
\end{abstract}

practices. Moreover, the routines offer the hyper-resolution LSM community a range of irrigation routines to better constrain irrigation decision-making at critical temporal (daily) and spatial scales $(<1 \mathrm{~km})$.

\section{Introduction}

Regional land surface models (LSMs) often ignore or do a poor job of representing irrigation physics (Kumar et al., 2015). This is in part due to the difficulty of validating irrigation amount estimates; irrigation datasets are rare, in formats that are difficult to work with on a regional scale (e.g., different reporting formats from one agency to another or in paper records), and have a latency period of months to years, making them impractical to use in operational forecasts. The USDA Farm and Ranch Irrigation Survey (USDA, 2014) contains survey data on the county level; however, data are only reported every 5 years and irrigation data are given on a pumping volume basis instead of depth per irrigated area as needed by LSMs (Siebert et al., 2010). Another well-known irrigation database, AQUASTAT (FAO, 2008), contains irrigation data on a spatial scale too coarse for investigating important feedback, like land-atmospheric coupling, and lacks information for Europe and North America. There are only a few studies that have used field-level irri- 
gation databases ( Grassini et al., 2011, 2014, 2015), mostly focusing on benchmarking on-farm irrigation in relation to crop production.

With the continual refinement in the spatial resolution of LSMs down to $<1 \mathrm{~km}$ (Wood et al., 2011) and the coupling to crop models (Kucharik, 2003), reliable irrigation data need to be incorporated in the calibration and validation of LSMs. Although the presence of irrigation does not necessarily impact soil moisture contribution to the atmosphere, the soil moisture-flux relationship is critical to surface energy balance and atmospheric dynamics. One area of particular importance is the impact of soil moisture on atmospheric processes, such as rainfall recycling (Findell and Eltahir, 1997), the strength of atmospheric coupling (Koster et al., 2004), and planetary boundary layer dynamics (Santanello et al., 2011), all of which impact the skill in operational forecast models. More complicated is that both irrigation timing and volumes are based on human decision-making processes and biophysical requirements (Gibson, 2016). For example, the USDA found that $24 \%$ of producers relied on crop calendars, $16 \%$ on crop consultants, and $23 \%$ on in situ probe technology (USDA, 2014). Because irrigation decisions are dependent on both processes, reliable historical irrigation data are critical to understand why and how decisions were made in order to accurately represent the physics in hyper-resolution LSMs and operational forecast models. In the absence of irrigation data, LSMs have typically relied on mass balance approaches (Döll and Siebert, 2002; Wada et al., 2012) where irrigation amounts close the water balance. While a reasonable first approach, this methodology may introduce additional uncertainty into LSMs due to the complexity of representing the human decision-making process on water use. The uncertain irrigation schemes affect the time history of soil moisture and thus our ability to properly assess the impacts of human water use on coupled land-atmospheric model physics.

The focus of this study was to investigate historical irrigation use at the critical field scale $(\sim 0.8$ by $0.8 \mathrm{~km})$ in a study area of 3500 ha in western Nebraska, which sits on the edge of the US Corn Belt. This critical scale is defined as a point where human water decisions are made due to the history of land partitioning and the inherent geometry dictated by the landscape. While it is a relatively small area, the study site is an ideal location for assessing the sustainability of groundwater pumping for the irrigation of crops. The study area is a microcosm of many areas across the globe, where humans rely on groundwater withdrawals for their livelihoods (Mekonnen and Hoekstra, 2011). The study area is at a critical location on a boundary where irrigation supply volumes can no longer economically compensate for the deficit between potential evapotranspiration $\left(\mathrm{ET}_{\mathrm{p}}\right)$ and precipitation $(P)$. Of particular concern regarding impacts on both human and natural ecosystems are the resultant declines in the local water table due to irrigation (Young et al., 2014). For example, the southern portion of the High
Plains aquifer (HPA) has had significant groundwater depletion over the last 80 years, with losses of up to $50 \%$ in saturated thickness (Scanlon et al., 2012). In the northern HPA (Butler et al., 2016), where this study area is located, intense irrigation pumping has led to localized water table declines (specifically in Box Butte County and widespread throughout the neighboring Upper Republican Natural Resources District) but has yet to be widespread across the region (Young et al., 2013). Given low recharge (Szilágyi and Jozsa, 2013; Gibson, 2015; Wang et al., 2016) relative to irrigation pumping, rising global food and water demands (FAO, 2009), and the concomitant effects of climate change (Kumar, 2012), the sustainability of this study area and the overall HPA system in support of long-term irrigation agriculture is uncertain (Butler et al., 2016). The study presented here is an important first step in assessing water-saving technologies to continue to make irrigation agriculture sustainable; there is a critical need for this in meeting rising global food demands.

Here, we benchmark relatively long-term (2008-2014), field-specific flow meter irrigation amounts within the study area against a range of irrigation strategies. The data include information on 55 fields $(\sim 65 \mathrm{ha})$ producing maize under center pivot irrigation. Datasets at this critical LSM scale are rare due to privacy concerns and, as a result, are often aggregated to county and seasonal totals (USDA, 2014; USDANASS, 2014). This makes an assessment of irrigation depths over a given area difficult to ascertain. This study therefore fills a critical data need in the development and testing of the next generation of hyper-resolution LSMs and operational weather forecast models (Kumar et al., 2015). The next generation of LSMs will be essential to better assess the impacts of irrigation on the surface energy balance as well as to evaluate the long-term sustainability of groundwater resources in agricultural areas. We note that irrigation is a key component of global food security, accounting for $\sim 40 \%$ of global food production and $\sim 20 \%$ of all arable land (Molden, 2007; Schultz et al., 2005). There is no doubt that irrigation will continue to expand in the future.

The primary objective of this study is to benchmark historical irrigation amounts in the study area using different plausible physically based irrigation triggering routines. In the methods sections, we will summarize the four identified irrigation triggering routines: (1) crop model (CM), (2) precipitation delayed (PD), (3) evapotranspiration replacement (ET), and (4) vadose zone model where irrigation is triggered by a simulated pressure head $(\mathrm{H})$. In the results section, we will assess the impacts of annual variations in precipitation on irrigation and soil texture differences in the study area. In the discussion, we will provide a general framework for including plausible irrigation schemes in LSMs and discuss any expected changes in irrigation behavior as producers adopt various technologies into practice. The framework and irrigation schemes provide LSMs with a practical guideline for estimating irrigation depths and timing as 


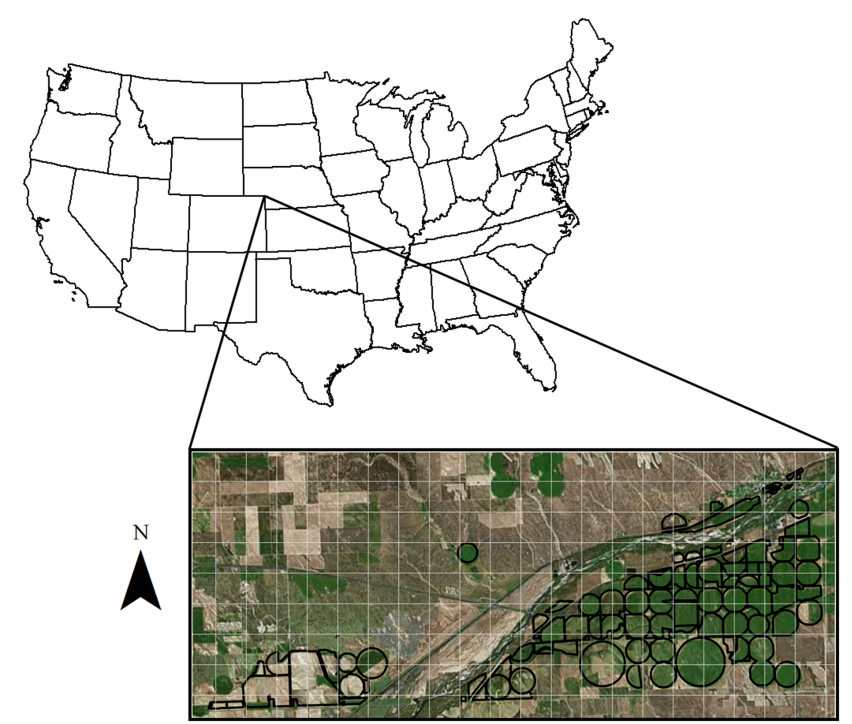

Figure 1. The study area located in western Nebraska with a $1 \mathrm{~km}$ grid (white lines) overlaid on the study site. The black lines show the individual field locations where irrigation volumes/depths are obtained from the SPNRD.

well as a strategy for investigating technology adoption scenarios.

\section{Methods}

\subsection{Description of study area and historical data}

The study area is located in western Nebraska where the South Platte River enters the state (Fig. 1). The site encompasses 55 fields with an average area of 65 ha under irrigated maize production ( 3500 ha total area). Overhead sprinkler irrigation from center pivots using water from the underlying HPA is the most common form of irrigation in this area as well as throughout Nebraska and the USA; it is a costeffective and more efficient option than flood irrigation. The study area is semiarid, and annual crop referenced (maize) evapotranspiration $\left(\mathrm{ET}_{\mathrm{c}}\right)$ is significantly higher than precipitation $(P)$ (HPRCC, 2016). The 7-year (2008-2014) average annual $P$ is $440 \mathrm{~mm} \mathrm{yr}^{-1}$ and average annual $\mathrm{ET}_{\mathrm{c}}$ is $820\left(\mathrm{~mm} \mathrm{yr}^{-1}\right)$, as measured by the High Plains Regional Climate Center weather station (HPRCC, 2016) located within $10 \mathrm{~km}$ of the study area near Brule, NE.

Data obtained from SSURGO (Soil Survey Staff, 2016) indicate that soil texture in the area falls within two USDA textural classes: sandy loam and loam (Fig. 2). Historical land management data for the area are available from the South Platte Natural Resources District (SPNRD, 2016). The SPNRD dataset includes field-specific information from 20082014 on crop type, irrigation pumping volumes, and irrigated area. Detailed descriptions and quality control of NRD databases can be found in Grassini et al. (2014) and Farmaha

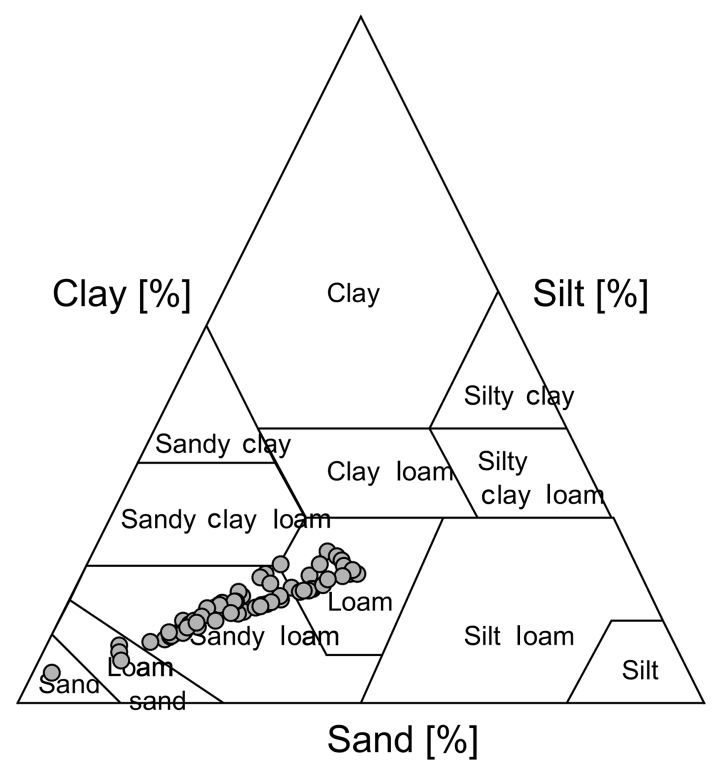

Figure 2. The area-weighted soil texture of all fields plotted on the USDA soil texture triangle, falling primarily in the sandy loam and loam textures. Data downloaded from the NRCS Web Soil Survey.

et al. (2016). The above datasets provide the needed meteorological forcing, model parameters, and calibration datasets for running and evaluating the suite of irrigation modeling routines described below.

\subsection{Irrigation modeling routines}

In the following sections, we will describe the four identified irrigation triggering routines: crop model $(\mathrm{CM})$, precipitation delayed (PD), evapotranspiration replacement (ET), and Hydrus-1D $(\mathrm{H})$. The four irrigation triggering routines represent the upper limit of irrigation requirements, in which no plant water stress occurs $(\mathrm{CM})$, and the lower irrigation limit needed to ensure minimal yield loss against a crop model benchmark $(\mathrm{H})$. Moreover, the four routines can be easily coupled or implemented into LSMs where PD is the simplest routine and $\mathrm{H}$ the most complex. We also note that the difference between historical irrigation practices and the lower bound of simulated irrigation provides a potential irrigation savings value in the study area. This irrigation savings value will be important for evaluating the economics of new irrigation technologies as well as providing critical information to policy makers and local stakeholders on the sustainable management of the HPA (Butler et al., 2016). Table 1 provides a summary of key needed inputs and a list of tunable parameters for each routine.

\subsubsection{Crop model irrigation (CM)}

A crop model, Hybrid-Maize (HM) (Yang et al., 2013), was utilized to estimate irrigation requirements and yield potential under an idealized scenario of crop growth with no wa- 
Table 1. Summary of needed inputs and tunable parameters for each irrigation routine.

\begin{tabular}{lll}
\hline Routine & Needed inputs & Tunable parameters \\
\hline $\mathrm{CM}$ & $P, \mathrm{ET}_{\mathrm{r}}$, soils & $\begin{array}{l}I \text { intensity }\left(\mathrm{mm} \mathrm{day}^{-1}, \text { growing season }\right. \\
\mathrm{ET}_{\mathrm{a}} / \text { growing season length) }\end{array}$ \\
\hline $\mathrm{PD}$ & $P$ & $I$ intensity \\
\hline $\mathrm{ET}$ & $P, \mathrm{ET}_{\mathrm{r}}, k_{\mathrm{c}}$ & $I$ intensity \\
\hline $\mathrm{H}$ & $P, \mathrm{ET}_{\mathrm{r}}, k_{\mathrm{c}}$, soils, $z_{\mathrm{r}}$ & $\begin{array}{l}I \text { intensity, pressure irrigation trigger } \\
\text { point, root depth irrigation trigger } \\
\text { point(s) }\end{array}$ \\
\hline
\end{tabular}

ter stress. The model performance has been extensively validated against measured yield in crops that received nearoptimal management across the Corn Belt (Grassini et al., 2009, 2011). However, it has not been rigorously tested for seasonal irrigation totals, which is one key outcome of this study. Details on the model can be found in Yang et al. (2013), and a brief description of the model is given here. Inputs to this model include meteorological data, soil texture, crop biophysical parameters, sowing date, and plant density. The datasets are described above in Sect. 2.1. The soil water dynamics over the root zone are simulated through a bucket model approach with $10 \mathrm{~cm}$ thick layers. Drainage between soil layers occurs when soil moisture exceeds field capacity. Irrigation application is triggered when actual ET $\left(\mathrm{ET}_{\mathrm{a}}\right)$ is less than crop referenced potential evapotranspiration $\left(\mathrm{ET}_{\mathrm{c}}\right)$, ensuring that no water stress occurs throughout the entire growing season. Irrigation depth is determined by the deficit of soil moisture defined by the current moisture level subtracted from $95 \%$ of field capacity within the managed root zone. Maximum water application per irrigation event was set to $19.5 \mathrm{~mm}$. When the depth-weighted unsaturated hydraulic conductivity $\left(K_{\mathrm{r}}\right)$ of the root zone is greater than or equal to $\mathrm{ET}_{\mathrm{c}}, \mathrm{ET}_{\mathrm{a}}$ is equal to $\mathrm{ET}_{\mathrm{c}}$. Otherwise, $\mathrm{ET}_{\mathrm{a}}$ is equal to the depth-weighted $K_{\mathrm{r}}$ of the root zone.

\subsubsection{Precipitation delayed irrigation (PD)}

Water application in an idealized land management operation would consider all components of the water balance within the decision-making process. However, in practice, precipitation is often the only component considered due to (1) the difficulty of accurately measuring the other water balance components and (2) the minimal relative economic return considering the perceived potential of crop yield loss versus savings due to reduced pumping/irrigation. With this in mind, producers often develop "rules of thumb" to irrigate up to a target total amount of water equal to irrigation plus in-season rainfall (in the study area, 1 May to 30 September). Using these basic rules of thumb and local crop calendar requirements, we suggest the following routine based on precipitation data alone. However, we note that this is not a recommendation for producer adoption, but instead represents a simplified method of irrigation management for modeling purposes. In addition, the applicability of this method to other regions should be possible with complementary datasets (i.e., $P$ and $\mathrm{ET}_{\mathrm{c}}$ ). Recommendations obtained from the SPNRD indicate that maize requires approximately $650 \mathrm{~mm}$ of total water (precipitation plus irrigation, $P+I$ ) per growing season (http://www.spnrd.org/index.html). Field observations indicate that irrigation often starts around midJune and concludes around mid-September, leading to a 100day irrigation season. Average irrigation application in the absence of precipitation would be $6.5 \mathrm{~mm} \mathrm{day}^{-1}$ or $19.5 \mathrm{~mm}$ per 3-day period. This irrigation depth is consistent with producer interviews and local expert knowledge. Three-day periods are critical to consider, as this is often the time required to perform a single $360^{\circ}$ rotation of a center pivot (i.e., dictated by soil infiltration rates and well pumping capacity). In this routine, if rainfall is greater than $6.5 \mathrm{~mm} \mathrm{day}^{-1}$, then irrigation for 1 day is met, and thus a 1-day delay is set. Likewise, for a rainfall event of $13 \mathrm{~mm} \mathrm{day}^{-1}$, then 2 days of irrigation are met and irrigation is delayed by 2 days, and so on for larger rain events. For simplicity, rain events and irrigation delays are rounded to the nearest day and up to a maximum 7-day delay. For rainfall events greater than $45.5 \mathrm{~mm} \mathrm{day}^{-1}$, we assume a maximum delay of 7 days due to deep drainage and runoff losses incurred during the event.

\subsubsection{ET replacement irrigation (ET)}

The primary purpose of irrigation is to ensure that $\mathrm{ET}_{\mathrm{a}}$ is able to adequately keep up with $\mathrm{ET}_{\mathrm{c}}$ over the growing season, as $\mathrm{ET}_{\mathrm{a}}$ is linearly correlated with yield (Passioura, 1977). Proper management allows a deficit between applied water and $\mathrm{ET}_{\mathrm{a}}$ in order to allow for adequate infiltration after rainfall. The deficit was assumed to be $6.5 \mathrm{~mm}$ for this routine based on the average daily crop water requirement discussed above. In this algorithm, when the deficit was greater than $6.5 \mathrm{~mm}$ during the irrigation season (15 June to 30 September), an irrigation event of $19.5 \mathrm{~mm}$ was triggered for the next day. Again, an irrigation event of $19.5 \mathrm{~mm}$ was used as it represents a 3-day period over which the center pivot operates.

Estimating $\mathrm{ET}_{\mathrm{c}}$ is necessary in order to track the deficit between applied water and $\mathrm{ET}_{\mathrm{a}}$. While estimating $\mathrm{ET}_{\mathrm{c}}$ is complex given the variability of micrometeorological variables from one field to another, in practical applications, crop coefficients are often used to surmise the differences in crop biophysical relationships and the effect of soil (Shuttleworth, 1993). These coefficients are often published by local services like the state climate office or the HPRCC in Nebraska.

Here, $\mathrm{ET}_{\mathrm{c}}\left(\mathrm{mm} \mathrm{day}^{-1}\right)$ was estimated by following the single crop coefficient method outlined in Allen et al. (1998):

$\mathrm{ET}_{\mathrm{c}}=\mathrm{ET}_{\mathrm{r}} K_{\mathrm{c}}$

where $\mathrm{ET}_{\mathrm{r}}\left(\mathrm{mm} \mathrm{day}^{-1}\right)$ is reference crop $\mathrm{ET}_{\mathrm{p}}$ calculated from micrometeorological variables and $K_{\mathrm{c}}$ is a dimensionless empirical constant that encompasses crop development as 
well as the average effect of soil on evaporation rates. Daily $\mathrm{ET}_{\mathrm{r}}$ data were determined from the HPRCC weather station data. $K_{\mathrm{c}}$ values were calculated as a function of growing degree day accumulation (GDD) from the HPRCC data (HPRCC, 2016). A single-day calculation of growing degrees $\left(\mathrm{GDD}_{\text {daily }}\right)$ is defined as

$\mathrm{GDD}_{\text {daily }}=\frac{T_{\max }+T_{\min }}{2}-T_{\text {base }}$,

where $T_{\max }$ is the daily maximum temperature $\left({ }^{\circ} \mathrm{C}\right.$ ) (with a maximum of $\left.30^{\circ} \mathrm{C}\right), T_{\min }$ is the daily minimum temperature $\left({ }^{\circ} \mathrm{C}\right)$, and $T_{\text {base }}$ is $10^{\circ} \mathrm{C}$. The GDD method is preferred as it more accurately represents a proxy for crop development, as opposed to a fixed number of days after sowing.

\subsubsection{Hydrus-1D irrigation (H)}

A physically based vadose zone model, Hydrus-1D (H1D) (Šimůnek et al., 2013), was used to simulate irrigation requirements based on predefined soil pressure head trigger points in the root zone. In order to carry out the necessary seasonal dynamics for annual crops (i.e., dynamic root growth, root distribution), we coupled the HM and H1D models using Matlab. We note that soil pressure triggered irrigation events based on more than one soil pressure value, flexible irrigation time frames, and dynamic root growth with a specified distribution are unavailable in the standard H1D code. Here we use Matlab to link together a series of 1-day simulations (totaling 7 years), where model outputs (pressure head at depth, flux rates, actual evapotranspiration, etc.) at the end of the day were used to make a decision about irrigation for the following day.

H1D simulates soil water dynamics and water flow with a numerical approximation of the 1D Richards' equation:

$$
\frac{\partial \theta}{\partial t}=\left(\frac{\partial}{\partial z}\right)\left[K(\theta)\left(\frac{\partial h}{\partial z}+1\right)\right]-S,
$$

where $\theta$ is volumetric water content $\left(\mathrm{cm}^{3} \mathrm{~cm}^{-3}\right), t$ is time (day), $z$ is the spatial location $(\mathrm{cm}), K(h)$ is unsaturated hydraulic conductivity $\left(\mathrm{cm} \mathrm{day}^{-1}\right), h$ is pressure head $(\mathrm{cm})$, and $S$ is a sink term describing evapotranspiration $\left(1 \mathrm{day}^{-1}\right)$. The soil profile simulated is $6 \mathrm{~m}$ deep with a $1 \mathrm{~cm}$ node discretization. Free drainage is set for the lower boundary condition, as local depth to groundwater is on average $15 \mathrm{~m}$ (Korus et al., 2013)

The H1D model requires that $\mathrm{ET}_{\mathrm{c}}$ be partitioned into potential evaporation and potential transpiration. This is accomplished using Beer's law:

$$
\begin{aligned}
& T_{\mathrm{p}}=\mathrm{ET}_{\mathrm{c}}\left(1-e^{-k \cdot \mathrm{LAI}}\right), \\
& E_{\mathrm{p}}=\mathrm{ET}_{\mathrm{c}}-T_{\mathrm{p}},
\end{aligned}
$$

where $T_{\mathrm{p}}$ is potential transpiration $\left(\mathrm{cm} \mathrm{day}^{-1}\right), E_{\mathrm{p}}$ is potential evaporation $\left(\mathrm{cm} \mathrm{day}^{-1}\right), k$ is the light extinction coefficient (set to 0.55; Yang et al., 2013), and LAI $\left(\mathrm{m}^{2} \mathrm{~m}^{-2}\right)$ is the leaf area index. For each year's growing season, we simulated a daily LAI time series using HM. This same seasonal dynamic was used for all simulations. In addition, HM was used to estimate the date of silking for each simulated year. Water stress is minimized during silking periods, as this is the most critical grain filling period for yield. Most producers will heavily water in this period to ensure yield. In order to accurately represent irrigation behavior, we forced irrigation events every 3 days, 1 week before and after the silking date. In cases where a simulated day occurred during the growing season, root depth $\left(Z_{\mathrm{r}}, \mathrm{cm}\right)$ and root distribution $\left(Z_{\mathrm{r}_{\mathrm{RD}}}\right.$, dimensionless) parameters were calculated on a daily basis from a predetermined GDD accumulation after the planting date for each growing season. This process was carried out following the equations outlined in the HM user manual (Yang et al., 2013):

$$
\begin{aligned}
& Z_{\mathrm{r}}=\frac{\mathrm{GDD}}{\mathrm{GDD}_{\text {silking }}} Z_{\mathrm{r}_{\text {max }}}, \\
& Z_{\mathrm{r}_{\mathrm{RD}}}=\exp \left(-\mathrm{VDC}_{L} / Z_{\mathrm{r}}\right),
\end{aligned}
$$

where $\mathrm{GDD}_{\text {silking }}$ is growing degree days at silking, $Z_{\mathrm{r}_{\max }}$ is a biophysical parameter representing the maximum depth the root zone can reach (in $\mathrm{cm}$ ) set to $150 \mathrm{~cm}$ (Yang et al., 2013), VDC is a vertical distribution coefficient set to 3 , and $Z_{L}$ is the current depth in the root zone $(\mathrm{cm})$.

Irrigation events and depths for the following day were calculated by investigating the average soil pressure heads at 30,60 , and $90 \mathrm{~cm}$ during the historical irrigation period from 15 June through 30 September. Prior to the silking date, the average soil pressure head at 30 and $60 \mathrm{~cm}$ is computed and compared against a preset irrigation trigger value set to $-500 \mathrm{~cm}$ based on the dominant soil types in the area (Fig. 2). Following the silking date, the average soil pressure is computed at 30,60 , and $90 \mathrm{~cm}$ with the same trigger point of $-500 \mathrm{~cm}$ of pressure. This algorithm is based on the best practice irrigation recommendations summarized in Irmak et al. (2014). In practice, producers vary the irrigation pressure trigger point based upon farmer risk aversion and soil type. Given that yield is the primary economic driver over energy costs for pumping water, this trigger point is often set at conservative values. When the pressure head at the considered depths exceeds the trigger point, an irrigation event of $19.5 \mathrm{~mm}$ is set for the following day. The irrigation event is added to any precipitation that may arrive randomly on that day as well.

In order to numerically advance the models through time, we set up a series of 1-day simulations and logical statements. If the model date occurred outside of the growing season (1 October to 30 April), no changes were made to precipitation and bare surface was simulated. If the model day was after planting (1 May) and before the start of the historical irrigation season (15 June), only the root zone depth and root distribution parameters were updated. For model dates during the irrigation season (15 June to 30 September), the root 

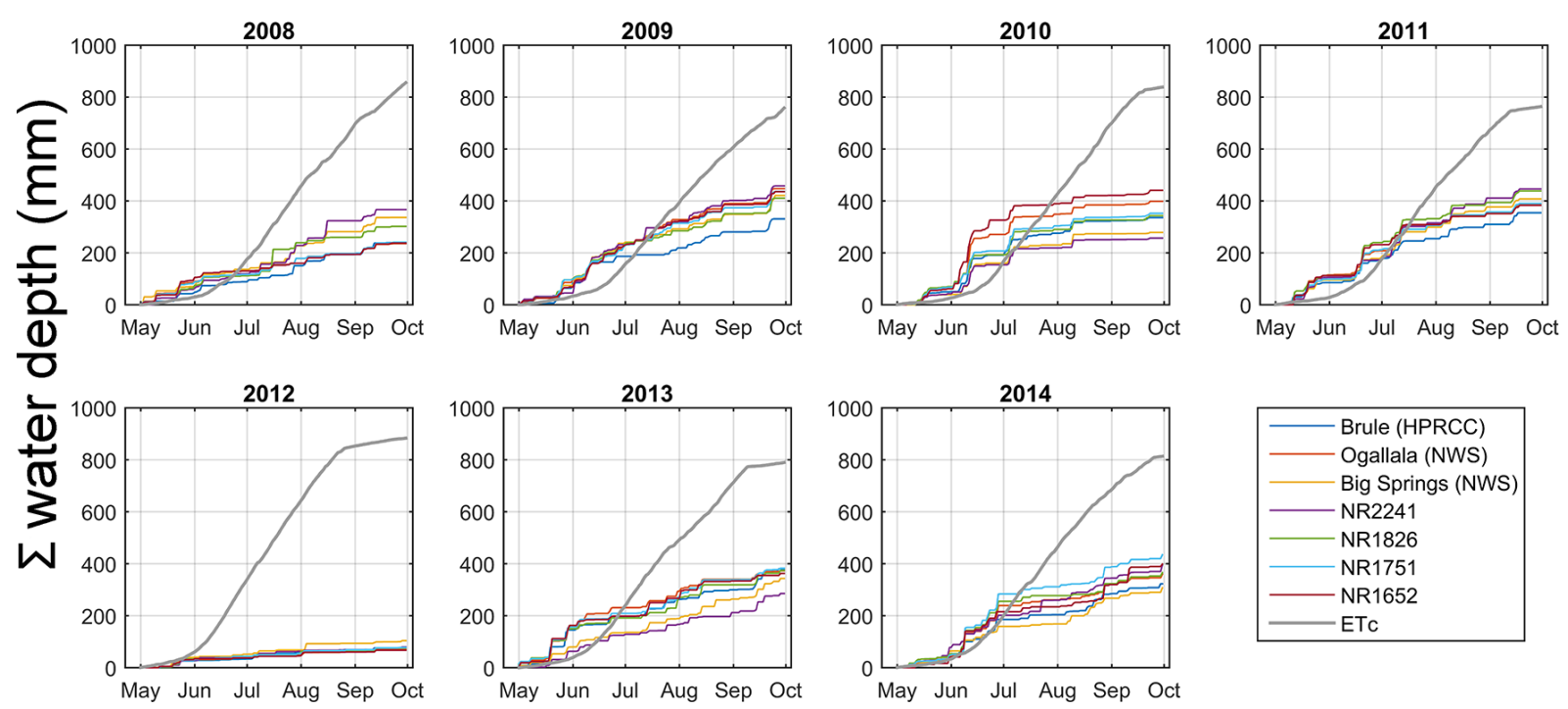

Figure 3. Cumulative in-season precipitation depths measured at seven rain gauges and crop referenced evapotranspiration $\left(\mathrm{ET}_{\mathrm{c}}\right) \mathrm{calculated}$ from a weather station $<10 \mathrm{~km}$ away. Precipitation variability tends to increase with increasing seasonal totals.

zone depth, root distribution, and irrigation amounts were changed for the following day. Using this routine, the model was run continuously at 1-day intervals for the entire study period (1 January 2008 to 31 December 2014).

\subsection{Rainfall variability across the study site}

Daily precipitation data for the years 2008-2014 were available from seven gauges within a $35 \mathrm{~km}$ radius of the study site. In order to help assess the effect of precipitation variability on irrigation application, all seven time series along with the average precipitation time series were used within the four irrigation routines described above. In addition, all irrigation routines that considered soil type were repeated for the two dominant soil types in the study area, i.e., sandy loam and loam.

\section{Results}

\subsection{Precipitation variability and $\mathbf{E T}_{\mathbf{c}}$}

As expected, significant gauge-to-gauge variability was observed within the seven rain gauge time series within each growing season with a mean of $320 \mathrm{~mm}$ and a coefficient of variation (CV) of $35 \%$ (Fig. 3). In general, as precipitation totals increased, the range of seasonal precipitation totals observed by the seven gauges increased as well (slope $=0.246 \mathrm{~mm} \mathrm{yr}^{-1}, R^{2}=0.38$ ). There was no consistent year-to-year spatial precipitation gradient, and no gauge consistently reported high or low totals. We hypothesize that this natural variability in rainfall is a large contributor to the irrigation variability we see at the field level. This hypothesis was beyond the scope of the current paper, but we sug-

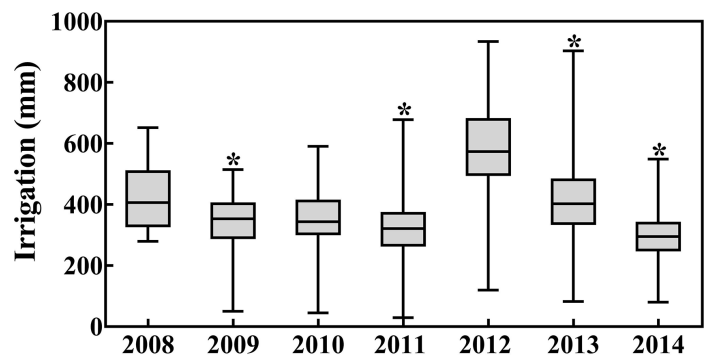

Figure 4. Box and whisker plots of historical irrigation depths for all sites. The upper and lower boundaries of the boxes indicate the 75th and 25th percentile, respectively. The horizontal line within the boxes is the median value. Whiskers are the maximum and minimum values. Asterisks indicate that irrigation distribution deviates from a normal distribution (D'Agostino-Pearson test, $p<0.01$ ).

gest future research in this area (cf. Gibson, 2016). In terms of growing season $\mathrm{ET}_{\mathfrak{c}}$, the HPRCC reported an average of $815 \mathrm{~mm}$ and was within $10 \%$ of the county-level values estimated by Sharma and Irmak (2012).

\subsection{Historical field-scale irrigation}

Average seasonal irrigation over the 2008-2014 period was $380 \mathrm{~mm}$ with a CV of $23 \%$. The distributions of irrigation amounts are provided in the box and whisker plots given in Fig. 4. Normal distributions and non-normal distributions with both negative and positive skewing were observed (D'Agostino-Pearson test, $p<0.05$ ). Growing season precipitation plus irrigation averaged $700 \mathrm{~mm}$ (Fig. 5) with a $\mathrm{CV}$ of $5 \%$. The highest seasonal irrigation average occurred during the growing season of $2012(580 \mathrm{~mm})$ due to an extremely dry growing season with only $80 \mathrm{~mm}$ of rainfall. We 


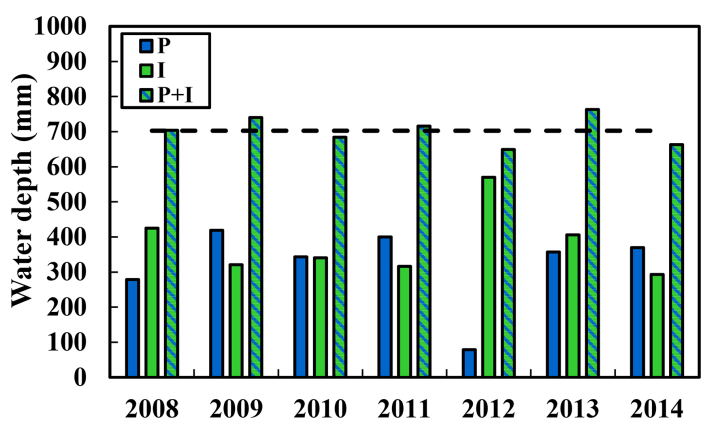

Figure 5. Observed growing season totals for precipitation $(P)$, irrigation $(I)$, and $P+I$. The dashed line represents the historical average for $P+I$.

found that soil texture was not a significant factor affecting irrigation application at the field scale in this region. This finding was consistent with results from central Nebraska (Gibson, 2016). After grouping the fields by soil type (loam and sandy loam), we found that the irrigation means for all years were not statistically different from each other (Student's $t$ test, $p=0.73$ ). This indicates that soil type did not factor into the irrigation decision-making process.

\subsection{Comparison of historical seasonal irrigation amounts with four irrigation routines}

The results of the comparison between the historical irrigation (2008-2014) and the four irrigation routines are summarized in Fig. 6. Both the $\mathrm{CM}$ and $\mathrm{PD}$ routines reproduce the trend of the historical irrigation amounts but with a low offset (similar slopes). CM irrigation water requirements were on average $80 \mathrm{~mm}$ lower ( $20 \%$ of total) relative to historical irrigation. For PD, the average seasonal difference was $40 \mathrm{~mm}$ lower (10\% of total). For ET and H, simulated irrigation amounts were $80 \mathrm{~mm}$ ( $20 \%$ of total) and $120 \mathrm{~mm}(30 \%$ of total) lower than the historical average, respectively. We also note that the slopes of the observed irrigations and the $\mathrm{CM}$ and PD for the given years were generally similar. However, it is obvious from Fig. 6 that the slopes of ET and H were different from the observations, which results in larger deviations in drier years and thus a potential for greater irrigation savings. The implications for water management will be discussed in the next section.

\subsection{Irrigation sensitivity to rainfall}

All irrigation routines responded to differences in the eight rainfall time series, and this response is represented as vertical error bars in Fig. 6. The difference between the highest and lowest irrigation amount for each growing season was on average $75 \mathrm{~mm}$, or $20 \%$ of average irrigation totals. The largest difference in irrigation totals occurred in 2008 for all irrigation routines with an average of $130 \mathrm{~mm}$ between all four routines, and the smallest difference occurred in 2012 at
Table 2. The van Genuchten parameters used in the Hydrus-1D simulations.

\begin{tabular}{lccccc}
\hline Texture & $\begin{array}{c}\theta_{\mathrm{r}} \\
(-)\end{array}$ & $\begin{array}{c}\theta_{\mathrm{S}} \\
(-)\end{array}$ & $\begin{array}{c}\alpha \\
(1 / \mathrm{cm})\end{array}$ & $\begin{array}{c}n \\
(-)\end{array}$ & $\begin{array}{c}K_{\mathrm{S}} \\
\left(\mathrm{cm} \mathrm{day}^{-1}\right)\end{array}$ \\
\hline Sandy loam & 0.048 & 0.385 & 0.0289 & 1.389 & 31.91 \\
Loam & 0.060 & 0.400 & 0.0127 & 1.458 & 10.85 \\
\hline
\end{tabular}

an average of $27 \mathrm{~mm}$ due to uniformly low precipitation. The analysis illustrates that the variation in irrigation amounts depends on which rainfall gauge is used to make a decision. Given that producers often have fields distributed across a region, the uncertainty in local rainfall directly propagates variations in irrigation amounts (Gibson, 2016). Future research efforts should investigate the effect of spatial rainfall variability on producer decision-making, but this was beyond the scope of the current study.

\subsection{Soil texture impact on irrigation routines}

We found that the two dominant soil textures in the study area did not have a significant impact on irrigation amounts under CM and H. ET and PD do not have a soil component considered in their routine and are therefore not impacted by soil texture. In the case of $\mathrm{CM}$, average irrigation was within $1 \%$ for all years. For $\mathrm{H}$, the irrigation average of the sandy loam soil was $10 \%$ lower than the average of the loam soil. The soil hydraulic parameters used for both soil textures were determined using ROSETTA (Schaap et al., 2001) and are presented in Table 2 .

\subsection{Simulated yield under irrigation routines}

Following the simulated irrigation for the routines of PD, ET, and $\mathrm{H}$, the $(P+I)$ time series were reinserted back into the crop model for all years to estimate yield impacts (Fig. 7). The crop model yielded an average of $14.6 \mathrm{Mg} \mathrm{ha}^{-1}$ over the study period. The yield gap (i.e., the difference between yield potential and actual yield) of US irrigated maize represents approximately $15 \%$ of the potential (Grassini et al., 2013; Global Yield Gap and Water Productivity Atlas, 2016), suggesting an average actual yield of $12.4 \mathrm{Mg} \mathrm{ha}^{-1}$ for the study area, which is within $5 \%$ of the historically reported yield. For the three routines and for all years, simulated yields were on average within $3 \%$ of the simulated yield based on the $\mathrm{CM}$. The results indicate that the various irrigation scheduling strategies did not have a large impact on yield, but they reduced irrigation amounts substantially; hence, they may be a sound economic option for producers.

\subsection{Simulated growing season irrigation application}

The daily time series of simulated irrigation application can be seen in Fig. 8. Data for the observed sub-growing season irrigation application are unavailable. Irrigation application 

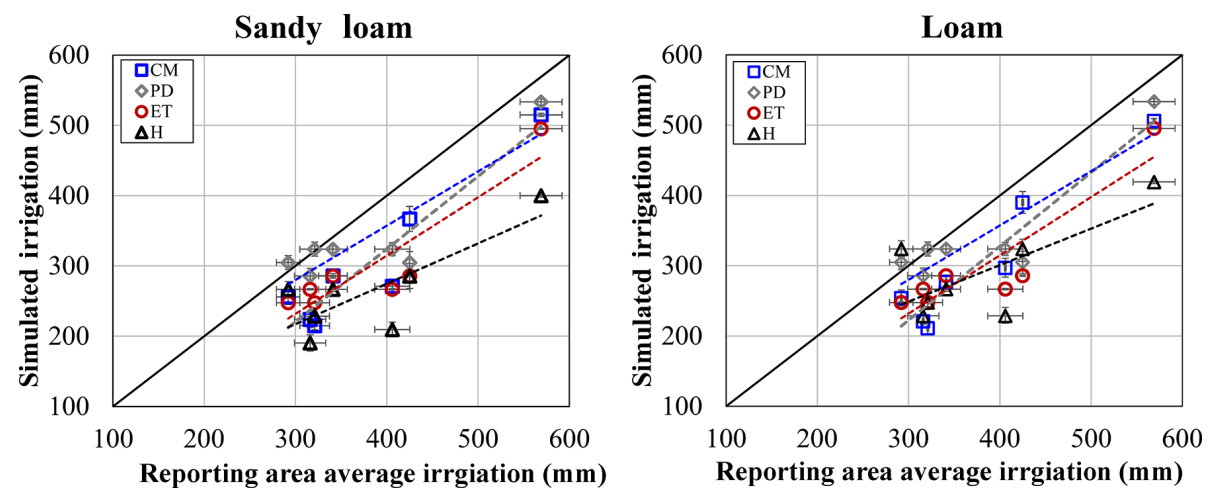

Figure 6. Historical irrigation vs. the four simulated irrigation routines for sandy loam (left panel) and loam (right panel). The vertical error bars are the standard error of the mean from the precipitation sensitivity analysis, and the horizontal error bars are the standard error of the mean from observed irrigation.

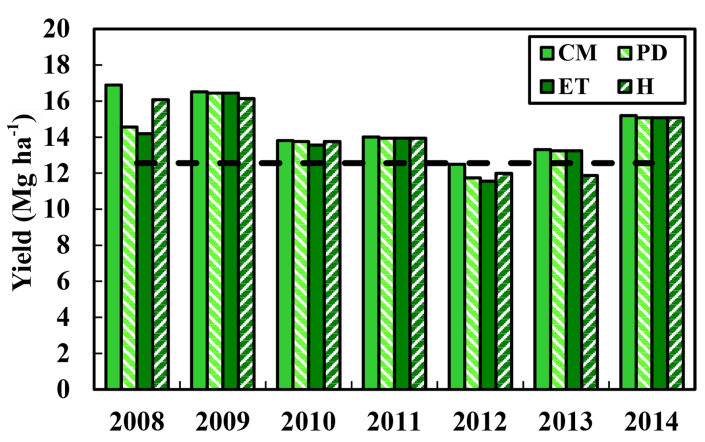

Figure 7. Potential yield simulated by Hybrid-Maize using the four irrigation routines: crop model (CM), precipitation delayed (PD), evapotranspiration replacement (ET), and Hydrus-1D (H).

tends to begin later in the growing season for the two routines that consider soil ( $\mathrm{CM}$ and $\mathrm{H})$. This is likely due to the routines allowing soil moisture to be depleted before irrigation is triggered, thus creating the reduced pumping and irrigation savings. The amount of soil moisture storage is typically near field capacity, but in exceptionally dry years (2012) this storage is reduced and thus will lead to less of a delay at the start of the growing season.

\section{Discussion}

\subsection{Temporal variability of applied irrigation}

Historically, the study area has had a consistent amount of total seasonal water $(P+I)$ from year to year. The percent of irrigation to applied water $(I /(P+I))$ was on average $55 \%$; notably in 2012 , this was as high as $88 \%$. The relative weight of irrigation to precipitation highlights the importance of constraining irrigation amounts for proper water balance closure within the study area, as well as in other areas with intense irrigation application. Given the high seasonal rates of irrigation to precipitation, no doubt the soil moisture will be adversely affected when compared to a rainfed area. More importantly, the impacts on the local surface energy balance (Santanello et al., 2011), rainfall recycling, and skill in observational forecasts may be diminished without properly accounting for irrigation. For example, regional mesoscale modeling illustrated that up to $40 \%$ of East African annual rainfall can be attributed to irrigation across India (de Vrese et al., 2016). With the suggested findings here on reduced irrigation needs (up to $115 \mathrm{~mm}$ or $30 \%$ ), the potential changes to precipitation patterns across the HPA due to the adoption of irrigation scheduling technology should be further investigated.

The study area is currently under groundwater appropriation, with a historical increase in depth to groundwater of $1.2 \mathrm{~m}$ from 1971 to 2013 (SPNRD, 2013; Young et al., 2013). Precipitation pattern changes in the area induced by global warming are believed to lead to less frequent but more intense storms with an increase in total precipitation (Dai, 2011). However, the timing of precipitation is of equal concern as totals, as more infrequent rain events may still lead to increased pumping with the same seasonal totals. The scenario of changing precipitation amounts and timing is not unique to the study area, but it is a more general pattern of the region; this highlights the need for explicit treatment of irrigation depths and timing to fully understand the complex feedback that exists beneath the land surface and atmosphere. The irrigation routines suggested in this work can be used as a first assessment of the likely irrigation amounts due to different observed scheduling practices (USDA, 2014).

\subsection{Spatial variability of applied irrigation}

The rainfall sensitivity analysis demonstrated the effects and uncertainty for each of the four irrigation routines investigated. Lower rainfall years had lower spatial variability and, as a result, simulated irrigation for each routine led to similar values. However, this behavior was not consistent with the observed irrigation data, in which the lowest rainfall 

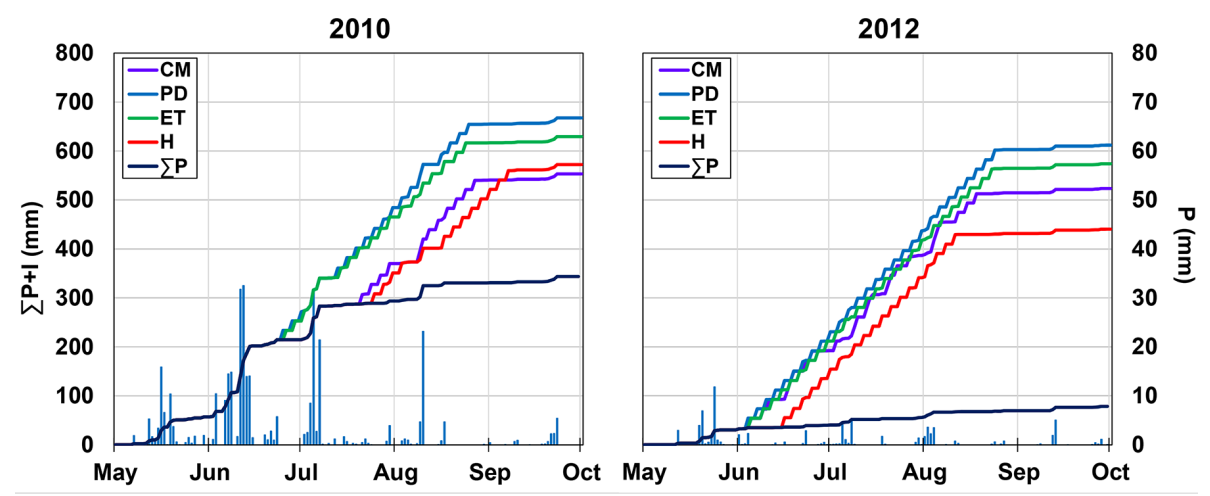

Figure 8. Example of simulated growing season cumulative $P$ and $P+I$ with daily $P$ values plotted on the secondary $y$ axis for the four irrigation routines in a wet (2010) and dry year (2012). Irrigation starts later for routines that track soil moisture, thus leading to reduced pumping.

year (2012) had the largest standard deviation $(168 \mathrm{~mm})$ for applied irrigation. The results are likely due to two reasons: (1) producers give up irrigation at some point during the growing season as their crop parishes in the extreme heat and drought conditions and (2) differences in well-to-well pumping capacity become more apparent with increased pumping demand. Although no direct work has been done to confirm differences in pumping capacity or inefficiencies in the study area, the general effect has been explored through modeling in other areas (Foster et al., 2014). With respect to LSMs, these two factors represent significant deviations from water balance closure approaches, making it challenging to include realistic irrigation values in dry years. Therefore, additional studies and datasets similar to those presented here are critical for the calibration and validation of the next generation of hyper-resolution LSMs.

With regard to soil texture differences in the study area, observed irrigation data indicated no difference between fields in these two texture classes. Similar behavior was seen from the irrigation routine simulations, which showed a $10 \%$ difference for $\mathrm{H}$ and a $1 \%$ difference for $\mathrm{CM}$. We note that given the similar soil texture classes (and thus the soil hydraulic parameters), this result is not unexpected. In practice, producers are beginning to adopt precision irrigation techniques (Hedley and Yule, 2009; Hedley et al., 2013). Smallscale features within a field (e.g., sandy or gravelly areas, underperforming parts of the field, waterways, pivot roads, etc.) can be better managed with the new technology. Therefore, managing fields by following one dominant soil type (i.e., irrigation pressure trigger point) may be highly inefficient (Kranz et al., 2014). More refined and consistent soil texture data across arbitrary political boundaries (Chaney et al., 2016) are needed to better account for differences in irrigation water application on the subfield scale, especially in areas with increasing adoption of precision agriculture technology.

\subsection{Potential for reduced pumping}

The four irrigation routines represent different levels of allowable water stress that develop in the maize. The CM routine is the lowest risk approach with respect to yield and represents the modeled upper limit of required irrigation to maintain a stress-free management scenario. It is hypothesized that any irrigation application above this represents irrigation application due to risk aversion and will not appreciably increase yield. Comparisons between 2008 and 2014 indicate that the slopes of the applied irrigation from observed irrigation are indistinguishable, but with a bias of $\sim 80 \mathrm{~mm} \mathrm{yr}^{-1}$ more observed irrigation. This indicates that producers are averaging an additional three to four irrigation cycles beyond what the CM indicates. The differences in irrigation totals from the other three irrigation routines are the result of increasing allowable water deficits in the routines. A reduction of $115 \mathrm{~mm}$ or $30 \%$ in irrigation was observed for $\mathrm{H}$ when compared to the historical average. We note that this hypothetical scenario requires perfect management with full trust of the technology and may not be achievable in practical applications. However, we anticipate that a $50-75 \mathrm{~mm}$ reduction over a short technology adoption period (2-4 years) is feasible, particularly in areas with strong university extension programs and/or producer-to-producer knowledge exchange (Irmak et al., 2012). In addition, these hypothetically reduced pumping numbers may be useful to local, state, and federal policy makers in future water management decisions and investment in cost-sharing technology programs.

\subsection{Assessment of center pivot irrigation routines in hyper-resolution land surface models}

The four irrigation routines, although biased (i.e., containing an offset), capture year-to-year variation in irrigation in western Nebraska. Given the widespread use of center pivots, we expect the irrigation routines to capture year-to-year variation for the HPA and parts of the eastern USA. We note 
that the magnitude of the offset is likely related to local producer behavior and influenced by social norms and risk aversion. Gibson (2016) provides a fuller assessment of irrigation behavior throughout central Nebraska. We note that it is unclear how these routines would behave in areas with center pivots outside the USA (i.e., Brazil, South Africa, and Australia), where energy costs for pumping may be more restrictive drivers of human decisions on irrigation. An assessment of these routines in those areas would require further validation.

We believe that the routines, combined with a reasonable offset correction, could be easily incorporated into future hyper-resolution LSMs with the above routine descriptions and readily available LSM model output or datasets (see Table 1). Clearly, accurate and local precipitation is critical in driving these irrigation routines and capturing producer behavior. This topic deserves more research, particularly the opportunity to combine low-cost in situ gauges with radar and remote-sensing products. Additionally, we note that the four routines could be run offline in order to provide reasonable guesses of applied irrigation for a given irrigation season. This may be beneficial in representing processes not explicitly considered in LSMs (Kumar et al., 2015) or making future assessments and recommendations about water availability for managers. Finally, the four routines provide reasonable irrigation bounds and, more importantly, predictions about decreases in irrigation as technology is introduced and adopted in novel areas.

\section{Conclusions}

In this work, we describe four plausible and relatively simple irrigation routines that could be coupled to the next generation of hyper-resolution LSMs operating at scales of $1 \mathrm{~km}$ or less. The crop model irrigation outputs reproduce the year-toyear variability of the observed irrigation amounts with a low bias of $80 \mathrm{~mm} \mathrm{yr}^{-1}$. Predictions from the vadose zone model indicate potential irrigation savings of up to $120 \mathrm{~mm} \mathrm{yr}^{-1}$ for maize. In addition, daily precipitation variability across the study area was found to introduce significant variability in daily irrigation decision-making depending on which value was considered. Future work could focus on providing accurate real-time $1 \mathrm{~km}$ daily precipitation products through a combination of in situ low-cost gauges, radar, and satellite remote-sensing. Accurate and real-time precipitation remains a critical weakness in rural and vast landscapes. Given the clustering of irrigation fields in western Nebraska, the number of in situ gauges needed could be significantly reduced to provide high-density networks in key areas. The findings from this work may be useful to local water managers and stakeholders in evaluating potential water-saving technologies. In addition, the simple routines could be coupled to future hyper-resolution land surface models that seek to understand the degree of land-surface atmospheric cou- pling and the consequences for operational forecasts. This understanding is essential as society continually recognizes the importance of human activities for the global water cycle and invests more resources in understanding the water-foodenergy nexus.

\section{Data availability}

The meteorological data used in this paper was provided by the HPRCC (2016, http://www.hprcc.unl.edu/). Irrigation flow meter data was obtained from the SPRND and is not widely available for public use. Yearly summary reports are available from the SPNRD (http://www.spnrd.org/). Soil data was obtained from SSURGO (Soil Survey Staff, 2016, http:// websoilsurvey.sc.egov.usda.gov/App/HomePage.htm). Data and model subroutines can also be requested from the corresponding author.

Competing interests. The authors declare that they have no conflict of interest.

Acknowledgements. This research is supported financially by the Daugherty Water for Food Global Institute at the University of Nebraska. Trenton E. Franz and Haishun Yang would also like to acknowledge the financial support of the USDA National Institute of Food and Agriculture, Hatch project \#1009760. Access to field sites and datasets is provided by The Nature Conservancy, the Western Nebraska Irrigation Project, and the South Platte Natural Resources District. A special thanks to Jacob Fritton for critical insights into producer practices in the study area. Trenton E. Franz would like to thank Eric Wood for his inspiring research and teaching career. No doubt the skills Trenton E. Franz learned while at Princeton in formal course work, seminars, and discussions with Eric will serve him well in his own career.

Edited by: M. McCabe

Reviewed by: two anonymous referees

\section{References}

Allen, R. G., Pereira, L. S., Raes, D., and Smith, M.: Crop evapotranspiration: Guidelines for computing crop requirements, Irrig. Drain. Pap. No. 56, FAO, Rome, Italy, doi:10.1016/j.eja.2010.12.001, 1998.

Butler, J. J., Whittemore, D. O., Wilson, B. B., and Bohling, G. C.: A new approach for assessing the future of aquifers supporting irrigated agriculture, Geophys. Res. Lett., 43, 2004-2010, doi:10.1002/2016g1067879, 2016.

Chaney, N. W., Wood, E. F., McBratney, A. B., Hempel, J. W., Nauman, T. W., Brungard, C. W., and Odgers, N. P.: POLARIS: A 30-meter probabilistic soil series map of the contiguous United States, Geoderma, 274, 54-67, doi:10.1016/j.geoderma.2016.03.025, 2016. 
Dai, A.: Drought under global warming: A review, Wiley Interdiscip. Rev. Clim. Chang., 2, 45-65, doi:10.1002/wcc.81, 2011.

de Vrese, P., Hagemann, S., and Claussen, M.: Asian irrigation, African rain: Remote impacts of irrigation, Geophys. Res. Lett., 43, 3737-3745, doi:10.1002/2016g1068146, 2016.

Döll, P. and Siebert, S.: Global modeling of irrigation water requirements Petra Do, Water Resour., 38, 8-1-8-10, doi:10.1029/2001WR000355, 2002.

FAO - Food and Agriculture Organization of the United Nations: AQUASTAT: FAO's information system of water and agriculture, http://www.fao.org/nr/water/aquastat/data/query/index. html?lang=en (last access: 15 August 2016), 2008.

FAO - Food and Agriculture Organization of the United Nations: How to feed the world in 2050, Rome, Italy, 2009.

Farmaha, B. S., Lobell, D. B., Boone, K. E., Cassman, K. G., Yang, S. H., and Grassini, P.: Contribution of persistent factors to yield gaps in high-yield irrigated maize, Field Crops Res., 186, 124132,2016

Findell, K. L. and Eltahir, E. A. B.: An analysis of the soil moisturerainfall feedback, based on direct observations from Illinois, Water Resour. Res., 33, 725-735, doi:10.1029/96wr03756, 1997.

Foster, T., Brozović, N., and Butler, A. P.: Modeling irrigation behavior in groundwater systems, Water Resour. Res., 50, 63706389, doi:10.1002/2014WR015620, 2014.

Gibson, J. P.: Estimation of Deep Drainage Differences between Till and No-Till Irrigated Agriculture, MS Thesis, University of Nebraska-Lincoln, Lincoln, NE, 2015.

Gibson, K. E. B.: More Crop per Drop: Benchmarking On-Farm Irrigation Water Use for Crop Production, MS Thesis, University of Nebraska-Lincoln, Lincoln, NE, 2016.

Global Yield Gap and Water Productivity Atlas: available at: http: //www.yieldgap.org, last access: 7 July 2016.

Grassini, P., Yang, H. S., and Cassman, K. G.: Limits to maize productivity in Western Corn-Belt: A simulation analysis for fully irrigated and rainfed conditions, Agr. Forest Meteorol., 149, 12541265, doi:10.1016/j.agrformet.2009.02.012, 2009.

Grassini, P., Yang, H. S., Irmak, S., Thorburn, J., Burr, C., and Cassman, K. G.: High-yield irrigated maize in the Western US Corn Belt: II. Irrigation management and crop water productivity, Field Crop. Res., 120, 133-141, 2011.

Grassini, P., Torrion, J. A., Cassman, K. G., and Specht, J. E.: Benchmarking yield and efficiency of corn \& soybean cropping systems in Nebraska, University of Nebraska-Lincoln, Lincoln, NE, 2013.

Grassini, P., Torrion, J. A., Cassman, K., Specht, J., Grassini, P., Torrion, J. A., Cassman, K. G., Yang, H. S., and Specht, J. E.: Drivers of spatial and temporal variation in soybean yield and irrigation requirements in the western US Corn Belt Drivers of spatial and temporal variation in soybean yield and irrigation requirements in the western US Corn Belt, Field Crops Res., 163, 32-46, doi:10.1016/j.fcr.2014.04.005, 2014.

Grassini, P., Torrion, J. A., Yang, H. S., Rees, J., Andersen, D., Cassman, K. G., and Specht, J. E.: Soybean yield gaps and water productivity in the western U.S. Corn Belt, Field Crop. Res., 179, 150-163, 2015.

Hedley, C. B. and Yule, I. J.: A method for spatial prediction of daily soil water status for precise irrigation scheduling, Agr. Water Manage., 96, 1737-1745, doi:10.1016/j.agwat.2009.07.009, 2009.
Hedley, C. B., Roudier, P., Yule, I. J., Ekanayake, J., and Bradbury, S.: Soil water status and water table depth modelling using electromagnetic surveys for precision irrigation scheduling, Geoderma, 199, 22-29, doi:10.1016/j.geoderma.2012.07.018, 2013.

HPRCC: Weather and Climate Data via an Automated Weather Data Network from the NOAA High Plains Climate Center (HPRCC), High Plains Reg. Clim. Center, Univ. NebraskaLincoln, Lincoln, NE, available at: http://www.hprcc.unl.edu/ awdn/, last access: 7 August 2016.

Irmak, S., Burgert, M. J., Yang, H. S., Cassman, K. G., Walters, D. T., Rathje, W. R., Payero, J. O., Grassini, P., Kuzila, M. S., Brunkhorst, K. J., Van DeWalle, B., Rees, J. M., Kranz, W. L., Eisenhauer, D. E., Shapiro, C. A., Zoubek, G. L., and Teichmeier, G. J.: Large scale on-farm implementation of soil moisture-based irrigation management strategies for increasing maize water productivity, T. ASABE, 55, 881-894, 2012.

Irmak, S., Payero, J. O., VanDeWalle, B., Rees, J., and Zoubek, G. L.: Principles and Operational Characteristics of Watermark Granular Matrix Sensor to Measure Soil Water Status and Its Practical Applications for Irrigation Management in Various Soil Textures, Biol. Syst. Eng. Pap. Publ. Pap. 332, University of Nebraska-Lincoln, Lincoln, NE, 1-14, 2014.

Korus, J. T., Howard, L. M., Young, A. R., Divine, D. P., Burbach, M. E., Jess, M. J. and Hallum, D. R.: The Groundwater Atlas of Nebraska, 3rd Edn., Conservation and Survey Division, Resource Atlas No. 4b/2013, School of Natural Resources, University of Nebraska-Lincoln, Lincoln, 2013.

Koster, R. D., Dirmeyer, P. A., Guo, Z. C., Bonan, G., Chan, E., Cox, P., Gordon, C. T., Kanae, S., Kowalczyk, E., Lawrence, D., Liu, P., Lu, C. H., Malyshev, S., McAvaney, B., Mitchell, K., Mocko, D., Oki, T., Oleson, K., Pitman, A., Sud, Y. C., Taylor, C. M., Verseghy, D., Vasic, R., Xue, Y. K., Yamada, T., and Team, G.: Regions of strong coupling between soil moisture and precipitation, Science, 305, 1138-1140, doi:10.1126/science.1100217, 2004.

Kranz, W. L., Irmak, S., Martin, D. L., Shaver, T. M., and van Donk, S. J.: Variable Rate Application of Irrigation Water with Center Pivots, Nebraska Ext., available at: http://extension.unl.edu/ publications (last access: 1 August 2016), 2014.

Kucharik, C. J.: Evaluation of a Process-Based Agro-Ecosystem Model (Agro-IBIS) across the U.S. Corn Belt: Simulations of the Interannual Variability in Maize Yield, Earth Interact., 7, 1-33, 2003.

Kumar, C. P.: Climate Change and Its Impact on Groundwater Resources, Int. J. Eng. Sci., 1, 43-60, 2012.

Kumar, S. V., Peters-Lidard, C. D., Santanello, J. A., Reichle, R. H., Draper, C. S., Koster, R. D., Nearing, G., and Jasinski, M. F.: Evaluating the utility of satellite soil moisture retrievals over irrigated areas and the ability of land data assimilation methods to correct for unmodeled processes, Hydrol. Earth Syst. Sci., 19, 4463-4478, doi:10.5194/hess-19-4463-2015, 2015.

Mekonnen, M. M. and Hoekstra, A. Y.: The green, blue and grey water footprint of crops and derived crop products, Hydrol. Earth Syst. Sci., 15, 1577-1600, doi:10.5194/hess-15-15772011, 2011.

Molden, D. (Ed.): Water for Food, Water for Life: A Comprehensive Assessment of Water Management in Agriculture. Earthscane/International Water Management Institute, London, Colombo, Sri Lanka, 2007. 
Passioura, J. B.: Grain yield, harvest index, and water use of wheat, J. Aust. Inst. Agr. Sci., 43, 117-120, 1977.

Santanello, J. A., Peters-Lidard, C. D., and Kumar, S. V: Diagnosing the sensitivity of local land-atmosphere coupling via the soil moisture-boundary layer interaction, J. Hydrometeorol., 12, 766-786, doi:10.1175/jhm-d-10-05014.1, 2011.

Scanlon, B. R., Faunt, C. C., Longuevergne, L., Reedy, R. C., Alley, W. M., McGuire, V. L., and McMahon, P. B.: Groundwater depletion and sustainability of irrigation in the US High Plains and Central Valley, P. Natl. Acad. Sci. USA, 109, 9320-9325, doi:10.1073/pnas.1200311109, 2012.

Schaap, M. G., Leij, F. J., and van Genuchten, M. T.: ROSETTA: a computer program for estimating soil hydraulic parameters with hierarchical pedotransfer functions, J. Hydrol., 251, 163-176, 2001.

Schultz, B., Thatte, C. D., and Labhsetwar, V. K.: Irrigation and drainage: Main contributors to global food production, Irrig. Drain., 54, 263-278, 2005.

Sharma, V. and Irmak, S.: Mapping spatially interpolated precipitation, reference evapotranspiration, actual crop evapotranspiration, and net irrigation requirements in Nebraska: Part II Actual evapotranspiration and net irrigation requirements, T. ASABE, 55, 923-936, doi:10.13031/2013.41524, 2012.

Shuttleworth, W. J.: chap. 4: Evaporation, in: Handbook of Hydrology, edited by: Maidment, D., McGraw-Hill, New York, 1993.

Siebert, S., Burke, J., Faures, J. M., Frenken, K., Hoogeveen, J., Döll, P., and Portmann, F. T.: Groundwater use for irrigation - A global inventory, Hydrol. Earth Syst. Sci., 14, 1863-1880, doi:10.5194/hess-14-1863-2010, 2010.

Šimůnek, J., Šejna, M., Saito, H., Sakai, M., and van Genuchten, M. T.: The HYDRUS-1D Software Package for Simulating the OneDimensional Movement of Water, Heat, and Multiple Solutes in Variably-Saturated Media (v.4.17), Dept. Environ. Sci. CA, University of California Riverside, Riverside, California, 2013.

Soil Survey Staff: Soil taxonomy: A basic system of soil classification for making and interpreting soil surveys, 2nd Edn., Handbook 436, Natural Resources Conservation Service, US Department of Agriculture, available at: http://www.nrcs.usda.gov/ Internet/FSE_DOCUMENTS/nrcs142p2_051232.pdf, last access: 7 August 2016.

SPNRD: Spring 2013 Groundwater level report, http://www.spnrd. org/Html/resources_reports.html (last access: 15 July 2016), 2013.
SPRND: available at: http://www.spnrd.org/index.html, last access: 1 March 2016.

Szilágyi, J. and Jozsa, J.: MODIS-aided statewide net groundwaterrecharge estimation in Nebraska, Groundwater, 51, 735-744, doi:10.1111/j.1745-6584.2012.01019.x, 2013.

USDA: Farm and Ranch Irrigation Survey (2013), Washington, D.C., available at: www.agcensus.usda.gov/Publications/2012/ Online_Resources/Ag_Census_Web_Maps/Overview/ (last access: 21 June 2016), 2014.

USDA-NASS: 2012 Census of Agriculture - Nebraska State and County Data, available at:https://www.agcensus.usda.gov/ Publications/2012/Full_Report/Volume_1,_Chapter_1_State_ Level/Nebraska/nev1.pdf (last access: 15 June 2016), 2014.

Wada, Y., Van Beek, L. P. H., and Bierkens, M. F. P.: Nonsustainable groundwater sustaining irrigation: A global assessment, Water Resour. Res., 48, W00L06, doi:10.1029/2011WR010562, 2012.

Wang, T., Franz, T. E., Yue, W., Szilagyi, J., Zlotnik, V. A., You, J., Chen, X., Shulski, M. D., and Young, A.: Feasibility analysis of using inverse modeling for estimating natural groundwater recharge from a large-scale soil moisture monitoring network, J. Hydrol., 533, 250-265, 2016.

Wood, E. F., Roundy, J. K., Troy, T. J., van Beek, L. P. H., Bierkens, M. F. P., Blyth, E., de Roo, A., Doll, P., Ek, M., Famiglietti, J., Gochis, D., van de Giesen, N., Houser, P., Jaffe, P. R., Kollet, S., Lehner, B., Lettenmaier, D. P., Peters-Lidard, C., Sivapalan, M., Sheffield, J., Wade, A., and Whitehead, P.: Hyperresolution global land surface modeling: Meeting a grand challenge for monitoring Earth's terrestrial water, Water Resour. Res., 47, W05301, doi:10.1029/2010wr010090, 2011.

Yang, H. S., Dobermann, A., Cassman, K. G., Walters, D. T., and Grassini, P.: Hybrid-Maize (v.2013.4). A simulation model for corn growth and yield, Nebraska Coop. Extension, Univ. Nebraska-Lincoln, Lincoln, NE, 2013.

Young, A. R., Burbach, M. E., and Howard, L. M.: Nebraska statewide groundwater-level monitoring report: Nebraska water survey paper No. 81, available at: http://nlcs1.nlc.state.ne.us/ epubs/U2375/B002.0081-2013.pdf (last access: 15 June 2016), 2013.

Young, A. R., Burbach, M. E., and Howard, L. M.: Nebraska statewide groundwater-level monitoring report, Nebraska water survey paper No. 82, University of Nebraska-Lincoln, Lincoln, NE, 2014. 